Thomas Szasz

\title{
In conversation with Alan Kerr
}

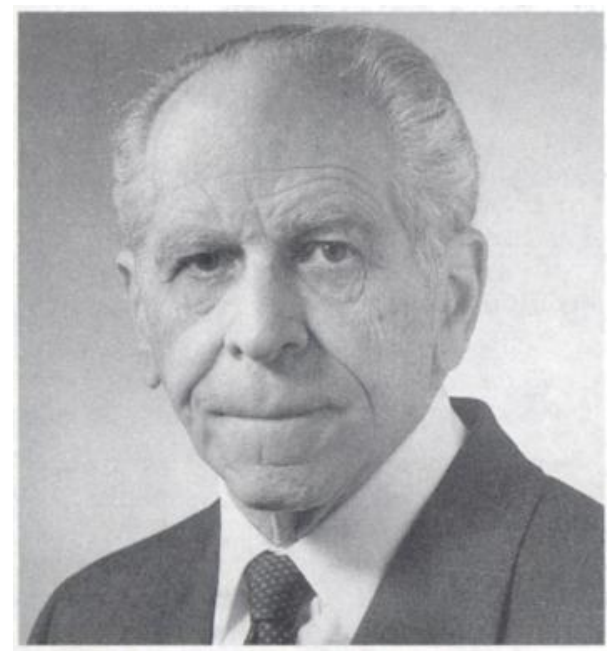

Thomas Szasz
Professor Thomas Szasz was born in Budapest in 1920. $\mathrm{He}$ emigrated to the United States at the age of 18 and qualified in medicine at the University of Cincinnati in 1944. He underwent a psychoanalytic training at the Chicago Institute for Psychoanalysis. From 1956 to 1990 he was Professor of Psychiatry at the State University of New York Health Center, Syracuse, New York, where he is now Emeritus Professor of Psychiatry.

Professor Szasz remains a prolific wrtter, having published 24 books and around 600 chapters, reviews and newspaper columns. His second book, The Myth of Mental IIIness: Foundations of a Theory of Personal Conduct, established his international reputation as a controversial writer on the nature of psychiatric disorders and their relationship to personal freedom.
Do you come from a medical background?

No. I am the first person in my family who chose to be trained as a physician.

What was your father's occupation?

He had a law degree but didn't practise law. He was a successful agricultural businessman in Hungary.

What recollections do you have of your early life in Budapest?

As this is an interview of a psychiatrist by a psychiatrist, I suppose one should start by saying something about one's parents and family. I don't want to romanticise it, but my father and mother were probably as good parents as a child could have. Actually, I had two mothers: my brother and I were raised by a governess who was very devoted to us. I was very devoted to her. As a result, I became aware, at an early age, of her utter economic dependence on my father. This was a source of anxiety and bewilderment for me.

My brother, George, who is two years older, has played a very important role in my life. He was a
Wunderkind. There was competition between us, of course. He was better than I in everything. except ping-pong. But he was unceasingly supportive. He earned a PhD in physical chemistry, worked in Switzerland, is now retired and lives in Zurich. Despite the physical separation, we have remained very close. He critiques virtually everything I write. I feel boundlessly indebted to him.

\section{What sort of education did you have in Hungary?}

School attendance was compulsory only to the age of 12. There were a variety of secondary schools, most of them operated by the three principal religious bodies, Catholic. Protestant. and Jewish, and a few secular Gymnasiums supported by the state. My brother and I attended one of the state-run schools that had very high standards. But it was a genuine meritocracy, great if you could hack it, not so great if you couldn't. Being expelled from school, by academic failure or even a relatively minor transgression, was an almost constant threat, or so it seemed to me. But that school together with my brother and parents - taught me to love learning, in the dual sense of loving to learn and loving to know. 
You left Hungary at the age of $18 ?$

That's right. In 1938. I must thank my parents and brother for that, too. After World War I, Hungary was not a promising place for a young person with aspirations for achievement and security. Although my family was only nominally Jewish, that fact also became important after 1933. acutely so after the Anschluss ${ }^{1}$. To make a long story short. I was planning to go to medical school in France. I spoke French fluently (then). One of my mother's cousin's was born and lived in Paris. I was there, in the summer of 1938, when my father informed me of their plan to emigrate to the United States and asked if I would go as well. Luckily. I said yes. Our move was facilitated by the fact that my father's brother, Otto, a mathematician of international renown, was in the first rank of those who lost their jobs after Hitler assumed power. He had been a professor in Frankfurt. In 1933 he was invited to teach at MIT (Massachusetts Institute of Technnology) and then obtained a permanent appointment at the University of Cincinnati. So we all ended up in Cincinnati.

And after the family settled in the US, you took an Honours degree in Physics at the University of Cincinnati. What career had you in mind at that stage?

I was keenly interested in physics. The education $I$ received in the Gymnasium in mathematics and physics was very advanced, the equivalent of college courses in the US. So I was headed towards working as a physicist.

But you did not continue to pursue that course.

No. Since my teens I had my heart set on going to medical school. It wasn't so much that I wanted to practise medicine, but rather that I wanted to know how the machine we inhabit works. It seemed to me - it still seems to me - that it is absurd that we should know more about what's under the hood of our car than under our rib cage. However, after we came to America, a medical education seemed beyond my reach, for two reasons. One was that we had virtually no money. The other was that, before World War II. medical education in the United States was largely closed to Jewish students. That was the famous "quota system". I was familiar with that from Hungary. There were a few medical schools for blacks and women, but in the main they too were excluded from medicine. People don't like to remember these things. In many hotels up and down the East Coast there were signs at the reception desk "Jews not wanted here". I never saw a sign like that in Hungary. Although my grades were excellent, as a foreigner and a "Jew" I had slim prospects of being accepted for medical school.

The medical schools knew if an applicant was Jewish as members of the community and inferred it from the person's last name. They didn't know what to make of my name. Szasz is a characteristically Hungarian name. My father was not born with it. His name was Schlesinger. Before graduating from the Gymnasium, he and his brother "Magyarized" their name. It was a part of shedding one's German-Jewish identity, like immigrants to America adopting anglicised names upon arriving at Ellis Island ${ }^{2}$.

Because of my excellent academic record, I was tentatively accepted by several schools, pending a personal interview. Then I was asked: "What kind of a name is Szasz? Are you Jewish?" Then I was rejected. Although I did not think of myself as Jewish. I couldn't answer No.

But eventually you entered medical school in Cinctnnati and finished top of the class.

That is correct. It was very tough but very enjoyable. In some ways it was a repetition of my experience in the Gymnasium. Heavy demands. The expectation of serious work and good performance. But, again, a true meritocracy. After getting my MD degree I was an intern at the prestiglous Harvard Service at the Boston City Hospital. Then I returned to Cincinnati for a year's residency in internal medicine. Then I had another difficult existential encounter with myself. I was headed toward practising internal medicine. I found that prospect depressingly uninteresting and unchallenging. It would have meant submerging my interest in religion and politics, in law and literature. Psychoanalysis was in the cultural air I breathed in Budapest. So then I took the plunge, seeking training in psychoanalysis and the credentials of a psychiatric residency.

\section{So you started training in psychiatry 50 years ago?}

Right. I deliberately chose a residency that did not include work with involuntary patients. In those days, the University of Chicago Clinics had only an out-patient service and a consultation service; it had no in-patient service. I did not want to "work with" persons who did not want to be patients. The war in the Pacific wasn't over yet. The residency programme was embryonic. The faculty was minuscule and there was one resident, me.

You went to Chicago, then, primarly to receive psychoanalytic training?

Yes. I was familiar with the Chicago scene from my medical school days. A few graduates, slightly 
older than I, had gone to Chicago, ostensibly for a psychiatric residency, but mainly for psychoanalytic training. On the South Side of Chicago this phenomenon was dubbed "Drang nach Norden"3. (The Institute for Psychoanalysis was on the North Side.) Which brings up an episode I might mention. The Chairman of the Psychiatry Department, Henry Brosin, was a young man. We were friends; we played tennis regularly. One day he called me into his office and said: "Tom, you have only one year left of your residency. I don't think it's right that you should finish without having any experience with psychotic patients. I think you should do your third year at the Cook County Hospital." You know what I did? I said: "Henry, I tell you what. I quit." I didn't want to get into a discussion about my reasons for not wanting to work in a state hospital. Actually, it was not a particularly heroic thing to do. I was a promising candidate at the Chicago Institute. So I took my third year at the Institute for Juvenile Research, which was a part of the University of Illinois. Two years later I had my Boards as well as my Diploma from the Institute.

You were aware of ideas within yourself then that challenged orthodox psychiatry?

That is an understatement. I had to be careful lest my superiors, or even my colleagues, realised my profound disagreements with them.

\section{But you hadn't published them at that time?}

No. I realised that my rejection of the idea of mental illness and my repudiation of psychiatric excuses and coercions were not going to endear me to most people, especially psychiatrists. So I kept my ideas to myself.

Your views must have been worked out pretty much in isolation?

Very much so. But not really. No one who can read, who is educated, is intellectually isolated. I read Shakespeare and Adam Smith; Burke and de Tocqueville; Jefferson and Madison; Dostoevsky. Chekhov, and Tolstoy; Molière and Voltaire and Mark Twain. We need not invent new ideas to understand human affairs. It's enough to adapt the ideas important thinkers have bequeathed us to our present conditions.

While you were a resident in psychiatry you embarked on psychoanalytic training which lasted for three years or more.

That's right. I had read a good deal of psychoanalysis while I was in medical school and even earlier. I graduated from the Chicago Institute in 3 years, which I think was a record. I didn't confuse credentials with competence or knowledge. I wanted the credentials. I could take care of my own education. As Thomas Carlyle said: "The true university of these days is a collection of books".

Can I ask your views on the contributions of Freud to our thinking?

It is easy to overstate or understate his contribution. Freud entered the cultural scene when materialist psychiatry was reigning supreme. In part, he opposed this trend, by showing that ostensibly meaningless acts - dreams, so-called mental symptoms - had meaning. But he also supported and exploited the dominant psychiatric perspective - which continues to enslave psychiatry - by creating an ostensibly biological model of the "mental apparatus" and by claiming that listening and talking to "patients" was a bona fide medical treatment. Still, Freud's work. and the works of Jung and Adler, have had a lasting impact on psychiatry and modern culture. partly for the better, partly for the worse. It's hard to know, at this point, whether the good outweighs the bad or vice versa. It's a very mixed bag.

In the mid 1950s you went into the US Naval Reserve at the Bethesda Naval Hospital?

Yes. I was drafted in 1954, during the Korean War. Because of a heart murmur, I had been deferred during World War II and was thus subject to the so-called "doctor draft" that was in effect then. Being drafted turned out to be another lucky break: it got me away from Chicago, from the Institute for Psychoanalysis, where I was a staff member, and from full-time practise of psychoanalysis, which I felt was an impossible way to make an honest living.

\section{Did you practise psychiatry in the Navy?}

I suppose you could say I did. It was the only time I had involuntary patients. We were a good match. The servicemen didn't want to be in the Navy and played the role of mental patient. I didn't want to be in the Navy and played the role of military psychiatrist: My job was to discharge the men from the Service as "neuropsychiatric casualties". Actually, my two years in Bethesda were pleasant and productive. My official duties consumed only a few hours. I had time to spend with my family, read, and write. I wrote most of my first book, Pain and Pleasure, while in the Navy. I couldn't have done that in Chicago.

Why? Was it difficult to develop your own views in Chicago?

I think it would have been impossible. Seeing patients all day, including a half day on Saturdays - that's how we worked then - was exhaust- 
ing. One cannot do justice to patients with such a schedule, much less have a family life and do productive intellectual work. There is little patient turnover in a psychoanalytic practice. The analyst's economic needs seduce him to encourage his patients to become dependent on him, which is exactly the opposite of what he ought to do. Then he rationalises his behaviour - which, at some level, he probably realises is wrong - as necessary for "analysing the transference". Humbug. I felt I had to get away from all that - from the psychobabble, from the corrupting powerpolitics of the psychoanalytic training system. I had been casting about for an academic appointment - an atmosphere where I could think and work more freely, with less pressure to earn a living by doing therapy-even before I was drafted. Luckily, I found it in Syracuse, after my discharge from the Navy in 1956.

Two themes run through your writings. First, your view of disease in psychiatry derives from the Virchow concept of histopathological change. If there is no histopathology, there is no disease. Secondly, in psychiatry you believe that there has come about an epistemological shift from histopathology to psychopathology which you regard as fundamentally phoney. Is that accurate?

Yes. My basic thesis is simple and conventional, albeit it is now regarded as controversial, if not heretical. Like the traditional pathologist, I regard histopathology and other physico-chemical (e.g. radiological, etc.) evidence of a lesion as the Gold Standard of disease. Disease qua lesion is a bodily state defined as an abnormality. To be sure, the concept of disease entails a judgment: Not all abnormal bodily conditions are regarded as diseases; baldness, for example, is not a disease. Whereas sometimes a normal bodily condition for example (unwanted) pregnancy - is regarded as a disease. Benjamin Rush, a Founding Father of the United States as well as of American psychiatry, believed that Negritude - that is, having black skin - was a disease, a form of leprosy.

We must not confuse lesions with behaviours. Behaviours - boxing, drinking, smoking - can cause diseases but are not diseases. To be sure, any behaviour - for example, masturbation, homosexuality, eating too much or too little, smoking tobacco or marijuana - may be declared to be a disease. This process may be likened to declaring that a piece of paper is money. Such conventions are supported and/or enforced by shared belief, professional authority, or the power of the state. So long as most people accept a paper currency as money, it is "valuable". So long as people accept a psychiatric diagnosis as a disease, it is "valid". However, once people reject fiat money and fiat disease, each becomes worthless. The "soft currency", like the German Mark after World War I, then ceases to be money. And the psychiatric diagnosis, like homosexuality in our time, ceases to be a disease. The point is that, in psychiatry, we conflate and confuse several basic concepts - namely, diagnosis and disease; lesion and (mis)behaviour; illness (as lesion) and the patient role (as the subject's complaint and medical expectation, if any); illness and incompetence; and the lawfulness or lawlessness of the subject's behaviour.

Psychiatrists have tended to assume that schizophrenia, and for this there has been mounting evidence of late, has an organic basis.

It is difficult to clarify this conundrum in a few words. Bleuler defined schizophrenia as a brain disease and, in the main, psychiatrists, the medical profession, and the judiciary have accepted this definition. Your use of the word "assume" is helpful. Physicians don't assume that cancer of the breast or myocardial infarction are diseases. They know they are because these conditions meet the medical criteria of disease. What criteria of disease does schizophrenia meet? If it meets the standard criteria of medicine (pathology), then schizophrenia is a neurological disease, like, say, a brain tumour. But what would asymptomatic schizophrenia look like?

Let's assume, however, that schizophrenia is like astrocytoma. Who is the person who has this "schizophrenia-lesion"? Is he self-supporting or dependent on his family or the state? Is he a lawabiding person or a criminal? Is he seeking medical - or any other-help? Is he legally competent? Were the psychiatrist to conduct himself like an ordinary physician, his job would be limited to informing the patient of his diagnosis and recommendation for treatment and then waiting until the patient consents to, or rejects, further interventions. (I am assuming that the "schizophrenic" is in the presence of the psychiatrist voluntarily and is in fact seeking his opinion. Typically, such is not the case.)

This brings us on to the issue of compulsion which, of course, is unique in law in that somebody can be compulsorily detained without having done any wrong.

Absolutely.

Where psychiatrists encounter individuals with delusional beliefs which pose a threat to themselves or others, it may be decided to implement a compulsory order and admit the person to hospital for treatment against his or her wishes.

Seemingly, that is how the story starts. Historically - and in practice to this day - it begins the 
other way around - with confinement; then the diagnosis of disease is added, to rationalise and justify the intervention. The history of psychiatry does not begin with Virchow's concept of disease. It couldn't have begun with it because psychiatry - that is, the modern practice of mad-doctoring - antedates Virchow by some 200 years.

You began to put your views forward with the publication of The Myth of Mental Illness in 1961.

The publicity that book received makes that publication a sort of watershed. Actually, I started to publish my views in the mid 1950s, sotto voce, when I was still in the Navy. For example, in 1956 and 1957, I published critiques of malingering, which was then a psychiatric diagnosis; of civil commitment, as a form of social control; and of tranquillising drugs, that were then coming on the market, as "chemical straitjackets". My essay, titled "The myth of mental illness", appeared in 1960, in the American Psychologist, the official journal of the American Psychological Association.

Your views started to provoke colleagues in psychia try and I think there was a point reached around 1970 when American psychiatric journals would not publish your work.

Fortunately that was not true in England.

Not true in England but in the States?

Yes.

How did you cope with the intense anger, criticism and rejection from your colleagues?

Well, it wasn't easy or pleasant. But, at bottom, I am a solitary person. And I was never really alone. I always had my family, my brother, my children, a few friends and colleagues. I was comforted by their saying: "You are right, but how can you say such things?"

You held a chair at the State University of New York in Syracuse for 34 years.

Not a chair. I was a tenured professor, not the chairman of the department, a post to which I never aspired. I never wanted power over others. I avoided having power over patients or colleagues. In this respect, my model has been Spinoza. As you know, he was offered all sorts of prestigious appointments by princes, which he declined. His maxim was: "Leave me alone. Let me grind lenses and think my own thoughts."
Did you have medical students to teach? And if so what psychiatry did you teach them?

Yes. I taught them conventional psychiatry, Kraepelin and Bleuler and Meyer, things medical students ought to know. Those were the lenses I was grinding. I am often asked this question. My position, I feel, was similar to that of a Professor of Religion who teaches Catholicism in September. Protestantism in October, Buddhism in November. He doesn't have to believe in the truths of any of these creeds, but he ought to know what they are, and students ought to learn what they are. I also taught residents individual psychotherapy. which, unlike now, in the 1960s and 70s was considered to be the most important part of residency training.

How did you manage patients referred to you with severe mental disorders?

After I came to Syracuse in 1956, my private practice was always less than half time. Because of the way I worked, the problem you pose did not arise. Anyone who wanted to see me as a patient had to make his own appointment and had to pay me, directly. This excluded persons who did not really want to see a psychiatrist but were forced to do so by others, especially by legal coercion. My practice was not intended to cope with the problem that so-called severely ill mental patients pose, which all too often involves some form of lawless behaviour that people don't want to treat as badness or crime.

How much influence do you think your views have had?

I don't think that's a question for me to answer. I would like to say only that I think the immediate effect of my work has been to re-stimulate psychiatry's ever-latent penchant for proclaiming that it is simply a branch of medicine, that "mental illnesses are brain diseases". So I take some "credit" for the frenetic "remedicalisation" of psychiatry, for the claim that psychiatry is strictly biological, that mental illnesses are brain diseases. I think this view is embraced more fanatically in America than in Britain.

\section{You mean with DSM-III and $-I V$ and so forth.}

Exactly. Those are the symptoms of this malady. if I too may use the medical metaphor. The proliferation of DSMs is emblematic of a phoney, pseudoscientific progress - the pretence that fabricating psychiatric diagnoses is a new "science" that supposedly tells its practitioners that homosexuality is no longer an illness but that anorexia is an illness, as if psychiatrists had 
discovered something new about sex or selfstarvation.

You have written extensively on crime, sexual behaviour and drug taking. You feel that these areas do not lie within the scope of psychiatry and that if people wish to indulge or commit crimes they should be regarded as moral agents and held accountable.

Absolutely. Liberty and responsibility are, or ought to be treated as, two sides of the same coin. Civil commitment and the insanity defence are like Siamese twins. They cannot be separated. Both are grave moral wrongs. But, for modern western society, both are irresistibly convenient. I am equally opposed to psychiatric coercions and to psychiatric excuses.

You have written that psychiatry is a branch of law. not medicine.

Historically, the alienist's ${ }^{4}$ primary task was to control certain troublesome persons in certain medically rationalised ways - that is, by means other than criminal sanctions. That remains the psychiatrist's primary mandate, symbolised by civil commitment and the insanity defence typically followed by incarcerating the "innocent" defendant as "insane". Let me add that I believe that it is impossible to understand the insanity defence without tracing its roots to its origin in excusing self-murderers rather than murderers! I can't do justice to this subject here. I have written about it extensively. Psychiatry's mandate to protect people from themselves - masturbation in the old days, drugs and suicide today - is at the core of what I consider to be its intrinsically unscientific and morally problematic (to put it mildly) character. We are now mired in the results of this medicalisation of moral and social "problems", which we conceptualise as mental diseases and try to remedy by drugs and coercions we call "psychiatric treatments".

You write with precision and clarity and with a respect for language. But you also use words and phrases that seem deliberately provocative - like 'debauched' and 'torture', that Kraepelin, Bleuler and
Freud were 'conquistadors' or 'colonisers of the mind', that psychiatrists have 'a love affair with practising coercion which they peddle as care'.

You are kind. You could cite even more damaging examples!

Do you wish to heighten impact, or sometimes just add a touch of humour, as when you give approval to 'psychiatry between consenting adults'.

Both. I appreciate your generous comment about my effective use of the English language. I didn't know a word of English when I came to America. But it didn't take me long to fall in love with it. My first model was Bertrand Russell. He alerted me to the beauty and power of incisive and unpretentious English prose.

Your literary skills have been recognised in having received the H. $L$. Mencken award on three occasions. Mencken himself was described as a satirical, iconoclastic writer. Do you identify with those qualities.

Yes, indeed. I like Mencken. And Swift even more.

You retired from your University position at the age of 70 but remain extremely productive. Do you have time for other pursuits?

Yes. I have two grown daughters to whom I am very close. I have an adorable grandson. I talk to my brother regularly and visit him quite often. My family has always been very important to me. I have good friends. I lecture and travel a great deal and enjoy it very much. I walk. I read. I think.

\section{Notes}

1. The annexation of Austria by Nazt Germany in March 1938.

2. A small island in New York harbour. The traditional port of entry for immigrants on the East Coast.

3. After the World War I slogan. "Drang nach Osten" (Push to the East).

4 A psychiatrist who specialises in the legal aspects of mental illness. 